\title{
Chain Cleavage of Bioinspired Bacterial Membranes Photoinduced by Eosin Decyl Ester
}

Lucas G. Moreira ${ }^{1}$, Alexandre M. Almeida Jr. ${ }^{1}$, Sabrina A. Camacho ${ }^{1,2}$, Bianca M. Estevão ${ }^{2,3}$, Osvaldo N. Oliveira Jr. ${ }^{2}$, Pedro H. B. Aoki ${ }^{1}$

${ }^{1}$ School of Sciences, Humanities and Languages, São Paulo State University (UNESP), Assis, SP, 19806-900, Brazil

${ }^{2}$ IFSC, São Carlos Institute of Physics, University of São Paulo (USP), São Carlos, SP 13566-590, Brazil

${ }^{3}$ Department of Chemistry, State University of Maringá (UEM), Maringá, PR, 87020-900, Brazil 
EosDec/CLP are less displaced than both EosDec/DOPG and EosDec/DOPE monolayers. The extra negative charge of CLP may have significantly increased the electrostatic repulsion with EosDec expelling part of the photosensitizer molecules from the interface to the subphase, which can be noted by the lower mean molecular area around $30 \mathrm{mN} / \mathrm{m}$ on the $\pi$-A isotherms of Figure S1.

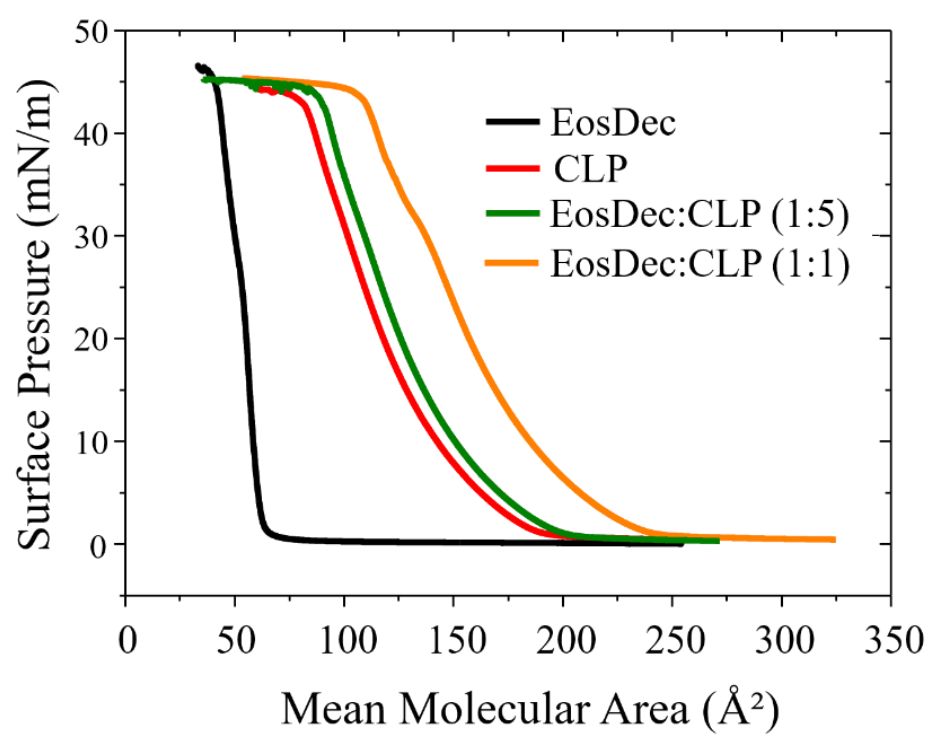

Figure S1. $\pi$-A isotherms of CLP neat and cospread monolayers with different ratios of EosDec (1:1 and 1:5). The $\pi$-A isotherm of neat EosDec (black line) was also added as a control. 

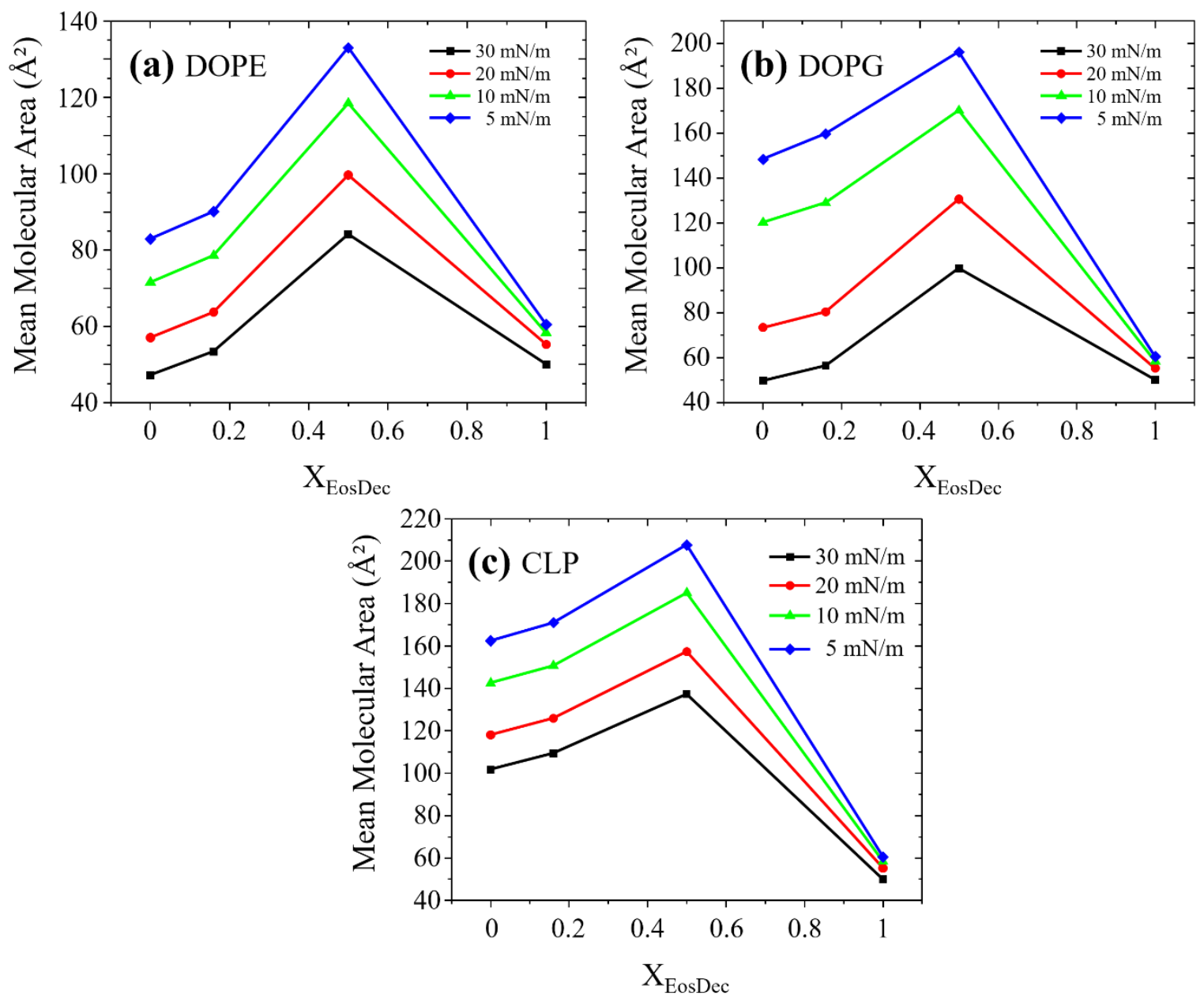

Figure S2. Mean molecular area $v s X_{\text {EosDec }}$ for DOPE, DOPG and CLP cospread monolayers at different surface pressures: 5, 10, 20 and $30 \mathrm{mN} / \mathrm{m}$. 
Table S1. Relative shifts in area $\left.\left[\left(\frac{A-A_{o}}{A_{o}}\right) x 100\right)\right]$ induced by EosDec into CLP monolayers. $A_{o}$ and $A$ are the extrapolated areas at $30 \mathrm{mN} / \mathrm{m}$ for the $\pi$-A isotherms of neat and cospread monolayers, respectively.

\begin{tabular}{cc}
\hline EosDec/CLP ratio & Relative shift \\
\hline $1: 1$ & $41.5 \% \pm 1.1 \%$ \\
$1: 5$ & $7.7 \% \pm 4.5 \%$ \\
\hline
\end{tabular}

Significant modifications on the PM-IRRAS spectra were only observed when the amount of EosDec was increased to 1:2 in the co-spread EosDec/CLP film, which is consistent to the less expanded isotherms observed at the 1:5 ratio (Table S1). Unlike DOPG, modifications in the phosphate groups of CLP were limited to the increased intensity of the $v_{\mathrm{s}}\left(\mathrm{PO}_{2}^{-}\right)$at $1174 \mathrm{~cm}^{-}$ ${ }^{1}$ and the $v\left(\mathrm{C}-\mathrm{O}-\mathrm{PO}_{2}^{-}\right)$at $1050 \mathrm{~cm}^{-1}$, as shown in Figure $\mathrm{S} 3 \mathrm{a}$. On the other hand, the $v(\mathrm{C}=\mathrm{O})$ shifts from $1738 \mathrm{~cm}^{-1}$ to $1729 \mathrm{~cm}^{-1}$ and has the intensity of the shoulder at $1772 \mathrm{~cm}^{-1}$ increased, suggesting the hydration of carbonyl groups ${ }^{1}$. In fact, shape and position of $v(C=O)$ depend on the hydration of lipid polar region and its surrounding polarity ${ }^{2}$, which may have been affected by the incorporation of EosDec. The $\mathrm{C}=\mathrm{C}$ and $\mathrm{C}_{6} \mathrm{H}_{5}$ stretching modes observed at 1558 $\mathrm{cm}^{-1}$ and $1445 \mathrm{~cm}^{-1}$ in the neat EosDec spectrum are displaced to $1567 \mathrm{~cm}^{-1}$ and $1456 \mathrm{~cm}^{-1}$ on the co-spread EosDec/CLP (1:2) film. The $v_{\text {as }}\left(\mathrm{CH}_{3}\right)$ intensity at $2956 \mathrm{~cm}^{-1}$ is significantly increased, as shown in Figure S3b. Moreover, the $\mathrm{I}_{\mathrm{v}_{S}\left(\mathrm{CH}_{2}\right)} / \mathrm{I}_{\mathrm{v}_{a s}\left(\mathrm{CH}_{2}\right)}$ ratio is increased from 0.43 to 0.85 , suggesting the disordering of the chains, as for DOPE and DOPG monolayers. Therefore, CLP monolayers were relatively less affected than DOPG, even at a higher concentration of EosDec. Although greater molecular repulsions might be the origin of the impairment for EosDec incorporation into CLP monolayers, the comparison with other phospholipids might not be straightforward since CLP is a dimeric phospholipid with four unsaturated carbon chains and two phosphatidyl groups linked by a central glycerol group ${ }^{3}$. The influence of the molecular interaction with EosDec over the carbonyl hydration and chain disordering is highlighted in Figure S3c. 

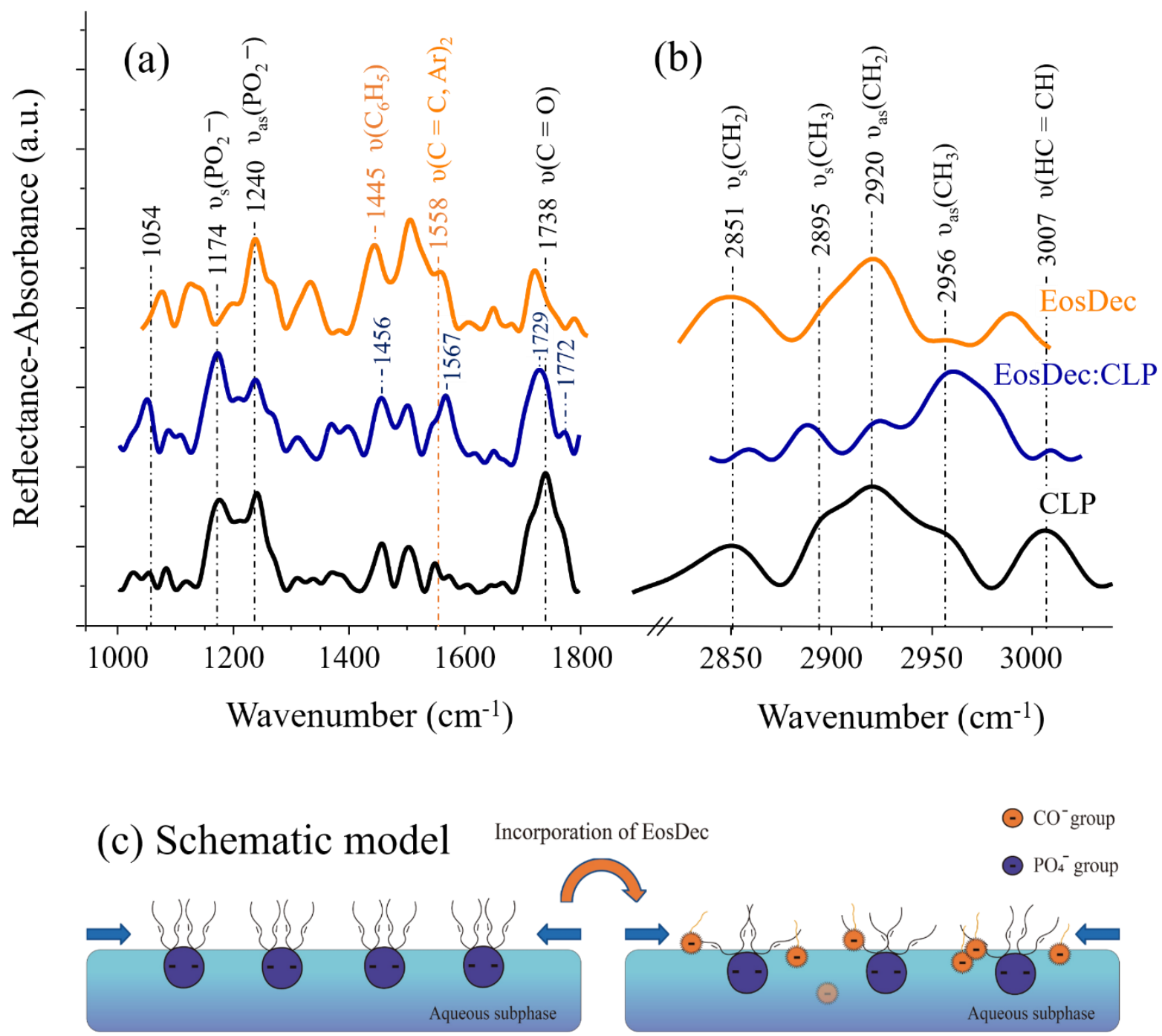

Figure S3. PM-IRRAS vibrational modes of (a) hydrophilic heads and (b) hydrophobic chains of neat CLP, EosDec and cospread EosDec/CLP (1:2) monolayers at $30 \mathrm{mN} / \mathrm{m}$ on aqueous subphase. (c) Proposed model for the interaction between EosDec - CLP. 
Table S2. Assignments of the main vibrational modes of neat CLP, EosDec and the cospread EosDec/CLP (1:2) Langmuir monolayers.

\begin{tabular}{|c|c|c|c|c|}
\hline \multirow{2}{*}{ assignments } & \multicolumn{3}{|c|}{$\operatorname{CLP}\left(\mathbf{c m}^{-1}\right)$} & \multirow{2}{*}{$\begin{array}{c}\text { EosDec }\left(\mathbf{c m}^{-1}\right) \\
\text { water }\end{array}$} \\
\hline & water & $1: 2$ & irrad & \\
\hline$v(\mathrm{HC}=\mathrm{CH})$ & 3007 & 3009 & 3013 & - \\
\hline $\mathrm{v}_{\mathrm{as}}\left(\mathrm{CH}_{3}\right)$ & 2956 & 2960 & 2960 & 2958 \\
\hline $\mathrm{v}_{\mathrm{as}}\left(\mathrm{CH}_{2}\right)$ & 2920 & 2924 & 2928 & 2921 \\
\hline$v_{s}\left(\mathrm{CH}_{3}\right)$ & 2895 & 2888 & 2888 & - \\
\hline$v_{s}\left(\mathrm{CH}_{2}\right)$ & 2851 & 2859 & 2839 & 2850 \\
\hline$v(C=O)$ & 1738 & $1729 / 1772$ & $1743 / 1802$ & 1720 \\
\hline$v(\mathrm{C}=\mathrm{C}, \text { Aromatic })_{2}$ & - & 1567 & 1568 & 1558 \\
\hline $\mathrm{v}(\mathrm{C}=\mathrm{C}, \text { Aromatic })_{1}$ & - & - & 1503 & 1506 \\
\hline$v\left(\mathrm{C}_{6} \mathrm{H}_{5}\right)$ & - & 1456 & 1456 & 1445 \\
\hline$v(\mathrm{C}-\mathrm{O})_{2}$ & - & 1267 & 1264 & 1267 \\
\hline$v_{\text {as }}\left(\mathrm{PO}_{2}^{-}\right)$ & 1240 & 1240 & 1240 & - \\
\hline$v(\mathrm{C}-\mathrm{O})_{1}$ & - & - & - & 1198 \\
\hline$v_{\text {as }}(\mathrm{C}-\mathrm{O}-\mathrm{C})$ & - & - & - & - \\
\hline$v_{s}\left(\mathrm{PO}_{2}^{-}\right)$ & 1174 & 1174 & 1177 & - \\
\hline$v\left(\mathrm{C}-\mathrm{O}-\mathrm{PO}_{2}^{-}\right)$ & 1054 & 1050 & 1031 & - \\
\hline
\end{tabular}

$* 1: 2=$ EosDec/lipid; irrad = Irradiated film 
Changes on the PM-IRRAS spectra of EosDec/CLP (1:2) film were also observed when compared the irradiated with the nonirradiated monolayers (Figure $\mathrm{S} 4)$. The $v\left(\mathrm{C}-\mathrm{O}-\mathrm{PO}_{2}^{-}\right)$band at $1050 \mathrm{~cm}^{-1}$ displaced to $1031 \mathrm{~cm}^{-1}$ and increased the intensity, while the $v_{\mathrm{s}}\left(\mathrm{PO}_{2}^{-}\right)$and $v_{\mathrm{as}}\left(\mathrm{PO}_{2}^{-}\right.$ ) bands at 1174 and $1240 \mathrm{~cm}^{-1}$, respectively, inverted their band intensities. The modifications in the phosphate groups might be related to strong and/or weak $\mathrm{H}$-bonding with the water molecules from subphase ${ }^{4}$. The effects of irradiation also impacted the hydrated and nonhydrated carbonyl ester groups, which shifted from 1729 and $1773 \mathrm{~cm}^{-1}$ to 1743 and $1802 \mathrm{~cm}^{-}$ ${ }^{1}$, respectively, suggesting changes in the hydration of lipid polar region and its surrounding polarity ${ }^{1,2}$. For the EosDec molecules, only the $v(C=C \text {, Aromatic })_{1}$ at $1503 \mathrm{~cm}^{-1}$ presented a change, enhancing the band intensity upon irradiation ${ }^{5,6}$. As for the alkyl chains, the $v_{s}\left(\mathrm{CH}_{2}\right)$ at $2859 \mathrm{~cm}^{-1}$ shifted to $2839 \mathrm{~cm}^{-1}$ and the $v_{\text {as }}\left(\mathrm{CH}_{2}\right)$ at $2924 \mathrm{~cm}^{-1}$ inverted its band intensity with the $v_{\text {as }}\left(\mathrm{CH}_{3}\right)$ at $2960 \mathrm{~cm}^{-1}$, resulting in a small enhance of the $\mathrm{I}_{v_{s}\left(\mathrm{CH}_{2}\right)} / \mathrm{I}_{\mathrm{v}_{a s}\left(\mathrm{CH}_{2}\right)}$ ratio, from 0.85 to $0.90^{7}$. Therefore, upon irradiation the packing of the lipid tails was practically not affected.
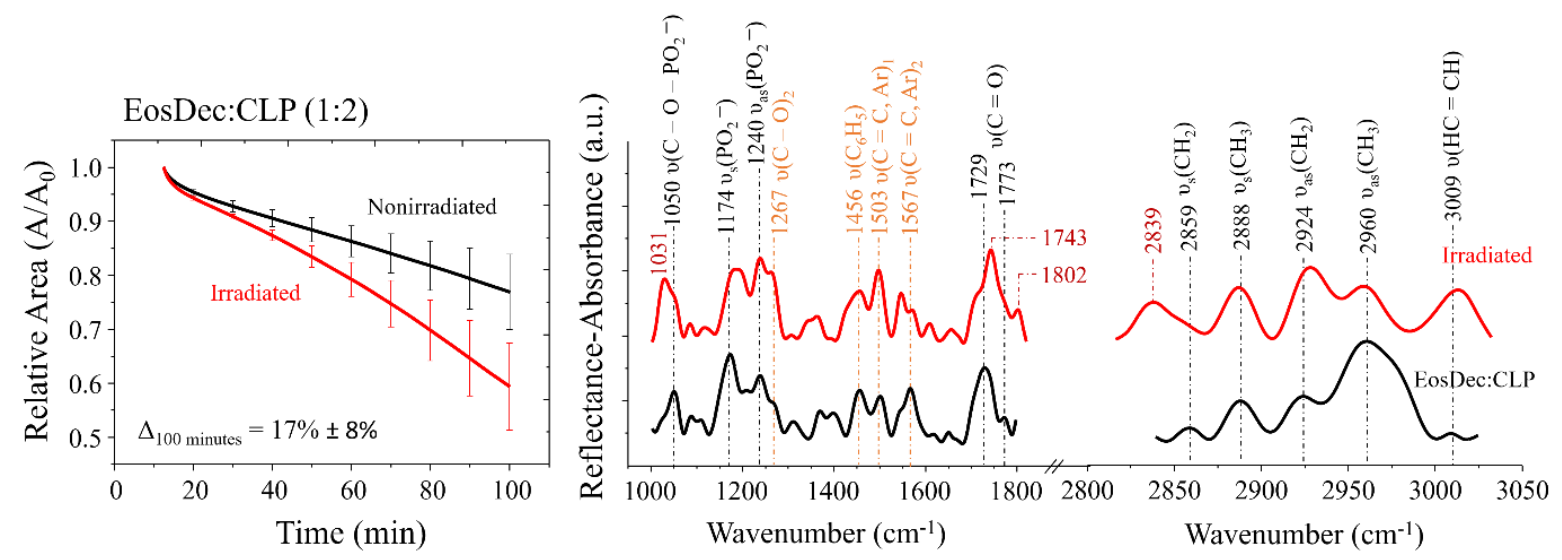

Figure S4. Relative area $\left(\mathrm{A} / \mathrm{A}_{0}\right)$ vs time (min) of nonirradiated (black lines) and irradiated (red lines) EosDec/CLP (1:2) monolayers. $\mathrm{A}_{0}$ is the extrapolated area at $30 \mathrm{mN} / \mathrm{m}$ of CLP isotherms. PM-IRRAS spectra for nonirradiated and irradiated cospread monolayers are shown in the right side. 


\section{References}

(1) Schmidt, T. F.; Caseli, L.; Oliveira, O. N.; Itri, R. Binding of Methylene Blue onto Langmuir Monolayers Representing Cell Membranes May Explain Its Efficiency as Photosensitizer in Photodynamic Therapy. Langmuir 2015, 31 (14), 4205-4212. https://doi.org/10.1021/acs.langmuir.5b00166.

(2) Fringeli, U. P.; Müldner, H. G.; Günthard, H. H.; Gasche, W.; Leuzinger, W. The Structure of Lipids and Proteins Studied by Attenuated Total-Reflection (ATR) Infrared

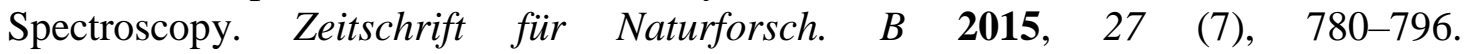
https://doi.org/10.1515/znb-1972-0712.

(3) Paradies, G.; Paradies, V.; De Benedictis, V.; Ruggiero, F. M.; Petrosillo, G. Functional Role of Cardiolipin in Mitochondrial Bioenergetics. Biochim. Biophys. Acta-Bioenerg. 2014, 1837 (4), 408-417. https://doi.org/10.1016/j.bbabio.2013.10.006.

(4) Arrondo, J. L. R.; Goñi, F. M.; Macarulla, J. M. Infrared Spectroscopy of Phosphatidylcholines in Aqueous Suspension a Study of the Phosphate Group Vibrations. Biochim. Biophys. Acta (BBA)/Lipids Lipid Metab. 1984, 794 (1), 165-168. https://doi.org/10.1016/0005-2760(84)90310-2.

(5) Zhang, F.; Shi, F.; Ma, W.; Gao, F.; Jiao, Y.; Li, H.; Wang, J.; Shan, X.; Lu, X.; Meng, S. Controlling Adsorption Structure of Eosin y Dye on Nanocrystalline TiO 2 Films for Improved Photovoltaic Performances. J. Phys. Chem. C 2013, 117 (28), 14659-14666. https://doi.org/10.1021/jp404439p.

(6) Estevão, B. M.; Pellosi, D. S.; De Freitas, C. F.; Vanzin, D.; Franciscato, D. S.; Caetano, W.; Hioka, N. Interaction of Eosin and Its Ester Derivatives with Aqueous Biomimetic Micelles: Evaluation of Photodynamic Potentialities. J. Photochem. Photobiol. A Chem. 2014, 287, 30-39. https://doi.org/10.1016/j.jphotochem.2014.04.015.

(7) Levin, I. W.; Thompson, T. E.; Barenholz, Y.; Huang, C. Two Types of Hydrocarbon Chain Interdigitation in Sphingomyelin Bilayers. Biochemistry 1985, 24 (22), 62826286. https://doi.org/10.1021/bi00343a036. 